\title{
Sex and the preimplantation embryo: implications of sexual dimorphism in the preimplantation period for maternal programming of embryonic development
}

\author{
Peter J. Hansen $^{1} \cdot$ Kyle B. Dobbs ${ }^{2} \cdot$ Anna C. Denicol $^{2} \cdot$ Luiz G. B. Siqueira $^{1,3}$
}

Received: 5 June 2015 / Accepted: 18 August 2015 / Published online: 21 September 2015

(C) Springer-Verlag Berlin Heidelberg 2015

\begin{abstract}
The developmental program of the embryo displays a plasticity that can result in long-acting effects that extend into postnatal life. In mammals, adult phenotype can be altered by changes in the maternal environment during the preimplantation period. One characteristic of developmental programming during this time is that the change in adult phenotype is often different for female offspring than for male offspring. In this paper, we propose the hypothesis that sexual dimorphism in preimplantation programming is mediated, at least in part, by sex-specific responses of embryos to maternal regulatory molecules whose secretion is dependent on the maternal environment. The strongest evidence for this idea comes from the study of colony-stimulating factor 2 (CSF2). Expression of CSF2 from the oviduct and endometrium is modified by environmental factors of the mother, in particular seminal plasma and obesity. Additionally, CSF2 alters several properties of the preimplantation embryo and has been shown to alleviate negative consequences of culture of mouse embryos on postnatal phenotype in a sex-dependent manner. In cattle, exposure of preimplantation bovine embryos to CSF2 causes sex-specific changes in gene expression, interferon- $\tau$ secretion and DNA methylation later in pregnancy (day 15 of gestation). It is likely that several embryokines can alter postnatal phenotype through actions directed towards the
\end{abstract}

Peter J. Hansen

hansen@animal.ufl.edu

1 Department of Animal Sciences, University of Florida, PO Box 110910, Gainesville, FL 32611-0910, USA

2 Department of Biology, Mugar 212-213, Northeastern University, 360 Huntington Avenue, Boston, MA 02115, USA

3 Embrapa Gado de Leite, Rua Eugenio do Nascimento, 610, Juiz de Fora MG 36038-330, Brazil preimplantation embryo. Identification of these molecules and elucidation of the mechanisms by which sexuallydisparate programming is established will lead to new insights into the control and manipulation of embryonic development.

Keywords Developmental programming .

Colony-stimulating factor 2 . Preimplantation embryo .

Protein diet $\cdot$ Embryo culture

\section{Introduction}

As used in this paper, developmental programming refers to the concept that alterations in the environment of the developing organism can result in a permanent or long-term change that is expressed phenotypically in adult life. In species as diverse as amphibians (Berg et al. 2009), reptiles (Schwanz et al. 2013), teleosts (Meier et al. 2010; Celeghin et al. 2011) and mammals (Roseboom et al. 2001; Walker and Ho 2012; Ganu et al. 2012; Fleming et al. 2015), alterations in the embryonic environment can have long-acting effects on development that extend into postnatal life. Mechanisms responsible for this phenomenon include changes in the epigenome (El Hajj et al. 2014; Desai et al. 2015) as well as in patterns of organogenesis and differentiation (Fleming et al. 2015; WoodBradley et al. 2015). Developmental programming can be beneficial when the deviation in adult phenotype prepares the individual for life in the anticipated postnatal environment but can be harmful when the actual environment is different than expected (Roseboom et al. 2001; Armitage et al. 2005; Gluckman et al. 2007; Warner 2014).

In mammals, adult phenotype can be altered by changes in maternal function early in pregnancy during the preimplantation period (Fleming et al. 2015). One characteristic of programming during this period is that the change in adult 
phenotype is often different for female offspring than for male offspring. Sexual dimorphism may reflect the differential benefit of altered adult phenotype to males and females (Warner 2014), as well as differences in evolutionary importance of reproductive success for each sex in various environments (Trivers and Willard 1973).

The purpose of this review is to describe sexual dimorphism in developmental programming during the preimplantation period and to propose one mechanism by which it occurs. In particular, it is hypothesized that the phenomenon is dictated by disparate actions on male and female embryos of maternally-derived embryo regulatory molecules whose secretion can be modified by the maternal environment. The evidence for this mechanism comes from study of the regulation of the preimplantation embryo by colony-stimulating factor 2 (CSF2). As will be discussed, CSF2 affects female embryos differently than male embryos and its secretion by the reproductive tract is altered by the maternal environment.

\section{Developmental programming occurs during the preimplantation period}

There is abundant experimental data to support the idea that perturbations in the environment of the preimplantation embryo can modify the phenotype of the resultant offspring in postnatal life (Tables 1,2). Among the maternal environmental factors that can alter postnatal phenotype are a low-protein diet, as shown in the rat (Kwong et al. 2000) and mouse (Watkins et al. 2008, 2010, 2011), reduced feed intake, observed in sheep (Hernandez et al. 2010), induction of inflammation through injection of lipopolysaccharide (LPS), shown in the mouse (Williams et al. 2011) and mating of female mice to males in which seminal vesicles have been surgically excised (termed SVX males) (Bromfield et al. 2014). In addition, culture of mouse embryos after removal from the maternal reproductive tract can affect postnatal function (Ecker et al. 2004; Sjöblom et al 2005; Watkins et al. 2007; Sampino et al. 2014). Moreover, the type of culture medium used to support development has been reported to cause changes in the developmental program, as demonstrated by addition of serum to culture medium of mouse embryos (Fernández-Gonzalez et al. 2004; Calle et al. 2012; Serrano et al. 2014). Biopsy of the mouse embryo has also been reported to alter postnatal phenotype (Sampino et al. 2014).

The particular postnatal modifications caused by perturbation in the embryo's environment vary somewhat between studies. This variation reflects, in part, differences between studies in the environmental signals used to change programming and, in part, differences in the type of observations made on offspring. Some postnatal changes can be considered to reduce offspring fitness while others could enhance fitness under certain environments. There is also a set of postnatal alterations that are observed repeatedly for several distinct alterations in the embryonic environment. Thus, for example, increased body weight and, often, fatness were observed for offspring derived from mothers fed low-protein diets (Kwong et al. 2000; Watkins et al. 2008, 2011), challenged with LPS (Williams et al. 2011) or mated to SVX males (Bromfield et al. 2014). Similar adult phenotypes were caused by embryo biopsy (Sampino et al. 2014), culture outside the reproductive tract (Sjöblom et al 2005; Sampino et al. 2014) and exposure to serum during culture (Fernández-Gonzalez et al. 2004). There are other indications of deviations in metabolic function in the postnatal period, including delayed glucose clearance, caused by mating to SVX males (Bromfield et al. 2014) and presence of serum in culture medium (Calle et al. 2012), increased plasma leptin concentrations (Bromfield et al. 2014) and increased incidence of liver steatosis (for embryos cultured with serum; Fernández-Gonzalez et al. 2004). Altered cardiovascular function was observed for offspring from mothers fed a low-protein diet (Kwong et al. 2000; Watkins et al. 2008, 2010, 2011), cultured during the preimplantation period (Watkins et al. 2007) and cultured in the presence of serum (Fernández-Gonzalez et al. 2004; Serrano et al. 2014). Postnatal behavior was also modified by changes in the preimplantation environment for low-protein feeding (Watkins et al. 2008), reduced feed intake (Hernandez et al. 2010), LPS injection (Williams et al. 2011), embryo biopsy (Sampino et al. 2014) and culture with serum (FernándezGonzalez et al. 2004).

Increased body weight and adiposity, disrupted glucose homeostasis and impaired cardiovascular function are features of the thrifty phenotype exhibited by offspring of mothers exposed to poor nutrition at various times during gestation (Roseboom et al. 2001; Hales and Barker 2001; Fisher et al. 2012; Ganu et al. 2012). Given that similar programming events have been observed following a variety of perturbations in the environment of the preimplantation embryo, there may be a common set of programming events in the preimplantation period that can be induced by disparate signals. Research with a wider range of species and environmental perturbations will resolve this question.

Postnatal phenotype of offspring derived from embryos fed a low-protein diet (Watkins et al. 2008) or derived from females mated to SVX males (Bromfield et al. 2014) remains disrupted when embryos are transferred to control females. Thus, developmental programming during this time is inherent in the embryo and not the result of alteration in maternal function later in pregnancy. Among the changes in the preimplantation embryo that are likely responsible for modifications of postnatal phenotype are alterations in gene expression (Kwong et al. 2006; Gad et al. 2012; Calle et al. 2012), the epigenome (Lucas 2013; Chen et al. 2013; Urrego et al. 2014; Sun et al. 2015) and patterns of embryonic growth and differentiation (Kwong et al. 2000; Eckert et al. 2012; Bromfield 
Table 1 Sexual dimorphism in developmental programming caused by alterations in the maternal environment during the preimplantation period

\begin{tabular}{|c|c|c|c|c|c|}
\hline \multirow[t]{2}{*}{ Species } & \multirow[t]{2}{*}{ Treatment } & \multicolumn{3}{|l|}{ Altered postnatal phenotype } & \multirow[b]{2}{*}{ Reference } \\
\hline & & Both sexes & Females only & Males only & \\
\hline Rat & $\begin{array}{l}\text { Low-protein diet, } \\
0-4.25 \text { days of } \\
\text { gestation }\end{array}$ & $\begin{array}{l}\text {-Increased body weight through } 7 \\
\text { weeks; no difference thereafter }\end{array}$ & & $\begin{array}{l}\text {-Increased systolic blood } \\
\text { pressure } \\
\text {-Increased kidney:body } \\
\text { weight and decreased } \\
\text { liver:body weight ratio }\end{array}$ & $\begin{array}{r}\text { Kwong } \\
\text { et al. } \\
2000\end{array}$ \\
\hline Mouse & $\begin{array}{l}\text { Low-protein diet, } \\
0-3.5 \text { days of } \\
\text { gestation }\end{array}$ & -Increased systolic blood pressure & $\begin{array}{l}\text {-Increased body weight through } 26 \\
\text { weeks of age } \\
\text {-Decreased heart:body weight ratio } \\
\text {-Altered behavioral responses }\end{array}$ & & $\begin{array}{l}\text { Watkins } \\
\text { et al. } \\
2008\end{array}$ \\
\hline Mouse & $\begin{array}{l}\text { Low-protein diet, } \\
0-3.5 \text { days of } \\
\text { gestation }\end{array}$ & $\begin{array}{l}\text {-Elevated lung angiotensin } \\
\text { converting enzyme, } 28 \text { weeks of } \\
\text { age (significant for males only) }\end{array}$ & & $\begin{array}{l}\text { - Attenuated vasodilation } \\
\text { response in mesenteric } \\
\text { arteries, } 22 \text { weeks of age }\end{array}$ & $\begin{array}{l}\text { Watkins } \\
\text { et al. } \\
2010\end{array}$ \\
\hline Mouse & $\begin{array}{l}\text { Low-protein diet, } \\
0-3.5 \text { ddays of } \\
\text { gestation }\end{array}$ & $\begin{array}{l}\text {-Increased systolic blood pressure } \\
\text { (significant for females only) } \\
\text {-Lower expression of } U c p 1 \text { in } \\
\text { retroperitoneal fat (significant for } \\
\text { males only) }\end{array}$ & $\begin{array}{l}\text {-Increased body weight from 11-28 } \\
\text { weeks of age; no effect after- } \\
\text { wards through } 52 \text { weeks } \\
\text { •Higher expression of Insr and } \\
\text { Igflr in retroperitoneal fat }\end{array}$ & & $\begin{array}{l}\text { Watkins } \\
\text { et al. } \\
2011\end{array}$ \\
\hline Sheep & $\begin{array}{l}\text { Reduced feed intake, } \\
\text { days }-2 \text { to } 30 \text { after } \\
\text { mating }\end{array}$ & & & $\begin{array}{l}\text {-Increased cortisol response } \\
\text { to isolation, } 4 \text { months of } \\
\text { age } \\
\text {-Increased escape attempts, } \\
\text { behavioral test, } 4 \text { months } \\
\text { of age }\end{array}$ & $\begin{array}{l}\text { Hernandez } \\
\text { et al. } \\
2010\end{array}$ \\
\hline Mouse & $\begin{array}{l}\text { Lipopolysaccharide } \\
\text { (LPS) challenge at } \\
\text { zygote stage }\end{array}$ & $\begin{array}{l}\text {-Reduced cytokine response to LPS } \\
\text { immune challenge }\end{array}$ & & $\begin{array}{l}\text {-Altered behavior } \\
\text {-Increased body mass index } \\
\text {-Increased fat pad: body } \\
\text { weight ratio }\end{array}$ & $\begin{array}{l}\text { Williams } \\
\text { et al. } \\
2011\end{array}$ \\
\hline Mouse & $\begin{array}{l}\text { Mating of females } \\
\text { with males without } \\
\text { seminal vesicles }\end{array}$ & $\begin{array}{l}\text {-Reduction in prepubertal growth; } \\
\text { increase in postpubertal growth }\end{array}$ & & $\begin{array}{l}\text {-Increased adiposity } \\
\text {-Increased plasma leptin } \\
\text { concentration } \\
\text {-Delayed glucose clearance }\end{array}$ & $\begin{array}{l}\text { Bromfield } \\
\text { et al. } \\
2014\end{array}$ \\
\hline
\end{tabular}

et al. 2014). Such changes may be particularly profound during the preimplantation period because it is at this time that the basic patterns of development are being established, including re-establishment of DNA methylation marks (Rivera and Ross 2013) and formation of the first differentiated cell lineages from which subsequent organs and tissues are derived.

Modifications in embryonic development in the preimplantation period can affect function of extraembryonic tissues much later in gestation. Thus, for example, culture of bovine embryos with the WNT antagonist dickkopf- 1 from days 5 to 7 of development resulted in embryos that were longer than control embryos at day 34 of gestation (Denicol et al. 2014). Additionally, the trophectoderm of blastocysts from mice fed a low-protein diet in the preimplantation period had greater capacity for fluid phase endocytosis than embryos from control females (Sun et al. 2014). Increased fluid-phase endocytosis was also observed for primitive endoderm-like lineages of embryoid bodies derived from low-protein embryos (Sun et al. 2014) and for the visceral yolk sac endoderm at days 12 and 17 of gestation (Watkins et al. 2008). Trophoblast giant cells at day 8 of gestation in placentae from mothers fed a low- protein diet during the preimplantation period exhibited greater growth than trophoblast giant cells of placentae that developed in control placentae (Watkins et al. 2015). By day 17 of gestation, placentae of conceptuses from mothers fed a lowprotein diet during the preimplantation period were smaller than for controls (Watkins et al. 2015).

\section{Female-male differences in programming of the preimplantation embryo}

One of the characteristics of developmental programming is that postnatal phenotype often varies between male and female offspring. This phenomenon is not limited to cases where the maternal environment is modified during the entirety of gestation or during mid- or late gestation (see Micke et al. 2010; Palou et al. 2012; Fisher et al. 2014; Khalyfa et al. 2015 for examples) but, as is summarized in Table 1 , also occurs for programming caused by changes in the maternal environment during the preimplantation stages of embryonic development. 
Table 2 Sexual dimorphism in developmental programming caused by culture or manipulation of preimplantation mouse embryos

\begin{tabular}{|c|c|c|c|c|c|}
\hline \multirow[t]{2}{*}{ Species } & \multirow[t]{2}{*}{ Treatment } & \multicolumn{3}{|l|}{ Altered postnatal phenotype } & \multirow[b]{2}{*}{ Reference } \\
\hline & & Both sexes & Females only & Males only & \\
\hline Mouse & $\begin{array}{l}\text { Culture, 2-cell to } \\
\text { blastocyst }\end{array}$ & $\begin{array}{l}\text {-Increased body weight } \\
\text { (effect persisted for } \\
\text { longer } \\
\text { after birth for males) }\end{array}$ & $\begin{array}{l}\text {-Increased placental } \\
\text { weight } \\
\text { of progeny when they } \\
\text { were pregnant }\end{array}$ & $\begin{array}{l}\text {-Increased fatness } \\
\text {-Decreased brain mass as } \\
\text { percent of total body mass }\end{array}$ & $\begin{array}{l}\text { Sjöblom et al. } \\
2005\end{array}$ \\
\hline Mouse & $\begin{array}{l}\text { Culture, 2-cell to } \\
\text { blastocyst }\end{array}$ & $\begin{array}{l}\text {-Increased systolic blood } \\
\text { pressure }\end{array}$ & & & $\begin{array}{l}\text { Watkins et al. } \\
2007\end{array}$ \\
\hline Mouse & $\begin{array}{l}\text { Culture, 8-cell to } \\
\text { blastocyst stage }\end{array}$ & $\begin{array}{l}\text {-Increased body weight at } \\
\text { week } 2 \text { of age and later } \\
\text { through week } 16\end{array}$ & & & $\begin{array}{l}\text { Sampino et al. } \\
2014\end{array}$ \\
\hline Mouse & $\begin{array}{l}\text { Biopsy of 8-cell } \\
\text { embryos }\end{array}$ & & & $\begin{array}{l}\text {-Increased body weight at weeks } \\
6,10 \text { and } 12-16 \text { of age } \\
\text { - Altered behavioral responses }\end{array}$ & $\begin{array}{l}\text { Sampino et al. } \\
2014\end{array}$ \\
\hline Mouse & $\begin{array}{l}\text { Culture from the } \\
\text { 1-cell stage with } \\
\text { serum vs culture } \\
\text { without serum }\end{array}$ & $\begin{array}{l}\text {-Altered behavior, elevated } \\
\text { plus maze }\end{array}$ & $\begin{array}{l}\text {-Increased body weight, } \\
\text { weeks } 31-70 \text { of age } \\
\text {-Increased incidence of } \\
\text { liver steatosis }\end{array}$ & $\begin{array}{l}\text {-Altered behavior, open field test } \\
\text {-Increased incidence of } \\
\text { perivascular } \\
\text { kidney inflammatory infiltration }\end{array}$ & $\begin{array}{l}\text { Fernández- } \\
\text { Gonzalez } \\
\text { et al. } 2004\end{array}$ \\
\hline Mouse & $\begin{array}{l}\text { Culture from the 1-cell } \\
\text { stage with serum vs } \\
\text { culture without se- } \\
\text { rum }\end{array}$ & & Not tested & $\begin{array}{l}\text {-Increased apopotis in testis } \\
\text { - Reduced sperm motility } \\
\text { - Reduced pregnancy rates in } \\
\text { females that males were } \\
\text { exposed to } \\
\text {-Delayed glucose clearance } \\
\text {-Insulin resistance }\end{array}$ & $\begin{array}{l}\text { Calle et al. } \\
\quad 2012\end{array}$ \\
\hline Mouse & $\begin{array}{l}\text { Culture from the 1-cell } \\
\text { stage with serum vs } \\
\text { culture without se- } \\
\text { rum }\end{array}$ & $\begin{array}{l}\text {-Increased body weight } \\
\text {-Increased mortality to } \\
20 \text { months of age }\end{array}$ & $\begin{array}{l}\text {-Increased systolic blood } \\
\text { pressure } \\
\text { Increased fat content } \\
\text {-Increased incidence of } \\
\text { hepatomegaly and liver } \\
\text { steatosis } \\
\text {-Decreased expression of } \\
\text { Fas, Lep, Ppara and } \\
\text { Pparg in white adipose }\end{array}$ & $\begin{array}{l}\text {-Increased plasma glucose } \\
\text { concentration } \\
\text {-Increased expression of Acox, } \\
\text { Ghr, Ppara and Ucpl in } \\
\text { white adipose }\end{array}$ & $\begin{array}{l}\text { Serrano et al. } \\
2014\end{array}$ \\
\hline
\end{tabular}

Some caution should be taken in interpreting interactions between embryonic sex and maternal environment because some apparent cases of sexual dimorphism may simply reflect sampling error. Thus, an effect of maternal environment might be significant in one sex but not the other due to the lack of experimental power. For example, male mice derived from mothers fed a low-protein diet during the preimplantation period had significantly elevated amounts of angiotensin converting enzyme in the lung (Watkins et al. 2010) and lower expression of $U c p 1$ in retroperitoneal fat (Watkins et al. 2011). While not statistically significant, numerical differences in these endpoints were also observed in females.

Even accounting for sampling error, however, there are many other endpoints where altered phenotype following preimplantation programming was observed in one sex without any indication for an effect in the other sex. Sexual dimorphism in alterations in postnatal phenotype has been observed in the low-protein diet model (Kwong et al. 2000; Watkins et al. 2008, 2010, 2011), and in response to reduced feed intake (Hernandez et al. 2010), LPS challenge (Williams et al. 2011), mating of female mice to SVX males (Bromfield et al. 2014), embryo biopsy (Sampino et al. 2014), embryo culture (Sjöblom et al. 2005) and presence of serum in embryo culture (FernándezGonzalez et al. 2004; Serrano et al. 2014).

The fact that programming of the preimplantation embryo in response to changes in the maternal environment differs between females and males is not surprising when one considers that gene expression differs between sexes in the preimplantation period. Alterations in the transcriptome of the embryo have been seen as early as has been examined: at the eight-cell stage in mice (Lowe et al. 2015) and the morula stage in cattle (Denicol et al. 2015). Initially, most differentially expressed genes are on the $\mathrm{X}$ or $\mathrm{Y}$ chromosomes (Denicol et al. 2015; Lowe et al. 2015) but more autosomal genes become differentially expressed by the blastocyst stage as shown in the mouse (Kobayashi et al. 2006) and bovine (Bermejo-Alvarez et al. 2010). The magnitude of difference in gene expression between sexes is of low magnitude for most genes. There was a 2-fold or greater difference in expression between sexes for only 11 of 391 differentially-expressed 
genes in the mouse (Kobayashi et al 2006) and 55 of 3756 genes in the cow (Bermejo-Alvarez et al. 2010).

The transcriptome is defined by the epigenetic environment and this too can differ between female and male embryos. Sexual dimorphism has been shown for specific methylation sites (Bermejo-Alvarez et al. 2008; Gebert et al. 2009) as well as globally. The pattern of histone methylation in embryonic stem cells derived from eight-cell mouse embryos differed between females and males in ways correlated with differences in gene expression (Lowe et al. 2015). Using an antibody to 5-methylcytosine to study bovine embryos, Dobbs et al. (2013a) found that differences in global methylation between sexes varied with stage of development. At the 6-8 cell stage, DNA was more methylated for female embryos than male embryos. Methylation increased thereafter but to a greater extent for males. By the blastocyst stage, males exhibited more DNA methylation than females (Fig. 1).

Sex-specific alteration in gene expression or in the structure of the embryonic epigenome caused by changes in the maternal environment during the preimplantation period could persist into fetal and postnatal life and result in sexual dimorphism in phenotype. Sex differences in maternal alterations in expression of an imprinted gene have been shown for the low-protein diet model in the rat (Kwong et al. 2006). Feeding a low-protein diet reduced expression of the imprinted gene H19 in male blastocysts but not in female blastocysts. Sex differences in the effect of protein feeding on $H 19$ expression persisted to day 20 of gestation for fetal liver but not for placenta.

\section{Embryokines as drivers of developmental programming of the preimplantation embryo}

Embryokines are defined as molecules produced by the oviduct and endometrium that regulate embryonic growth and development (Hansen et al. 2014a). These include not only protein hormones, growth factors and cytokines (Hansen et al. 2014b) but also various small molecules such as amino acids, which can regulate embryo development through the mTOR signaling pathway (Martin et al. 2003), prostacyclin I, which increases blastocyst hatching through activation of peroxisome proliferator-activated receptor $\delta$ (Kang et al. 2011) and endogenous cannabinoids, which act through various receptors to regulate development and implantation (Taylor et al. 2010).

As a class, embryokines are likely to be key mediators of developmental programming responses to changes in the maternal environment. In addition, alterations in developmental processes caused by embryo culture (Watkins et al. 2007; Farin et al. 2010; Chen et al. 2013; Sampino et al. 2014) could reflect, at least in part, the absence of critical maternal regulatory molecules or, for the case of addition of serum to culture

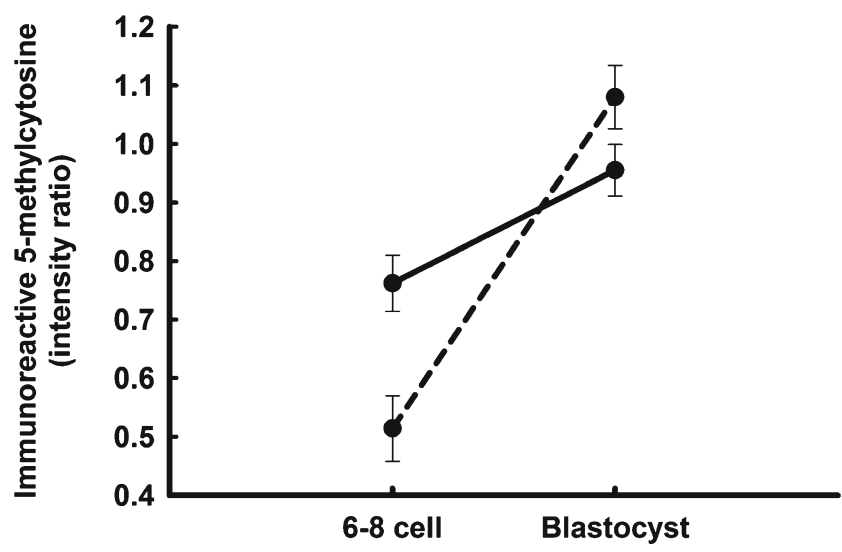

Fig. 1 Differences in immunoreactive 5-methylcytosine between female (solid line) and male embryos (dashed line) at the 6-8 cell and blastocyst stages of development in cattle. Data represent fluorescent intensity for anti-5-methylcytosine relative to that for nuclear propidium iodide. The figure is from Dobbs et al. (2013a) and is reproduced from PLOS ONE

medium (Fernández-Gonzalez et al. 2004; Calle et al. 2012; Serrano et al. 2014), alteration of embryonic function by bioactive molecules not normally involved in control of development. In addition to embryokines, developmental programming in utero or in culture could involve changes in cellular energy metabolism in the developing embryo. It has been shown that alterations in redox potential and mitochondrial activity of the mouse zygote caused by starvation, inclusion of pyruvate or lactate in the culture medium, or raising external $\mathrm{pH}$ can result in changes in body weight in the postnatal period (Banrezes et al. 2011).

There are two requirements for an embryokine to be considered as participating in developmental programming responses to changes in the maternal environment. Firstly, accumulation in the reproductive tract must be modified as a result of changes in maternal function. Secondly, actions of the embryokine on the embryo must cause a deviation in developmental dynamics that alters function of the offspring in postnatal life.

Much of the literature on developmental programming during the preimplantation period is based on the low-protein diet model developed by Tom Fleming and colleagues at the University of Southampton. This group proposed that the maternal signal to transmit information about protein nutrition to the embryo is the reduction in uterine luminal concentrations of the branched amino acids leucine, isoleucine and valine, which in turn leads to reduced mTORC1 signaling (Fleming et al. 2015). They showed that female mice fed a low-protein diet for the first 3.5 days of gestation experienced increased circulating concentrations of glucose and reduced circulating concentrations of insulin and free amino acids (Eckert et al. 2012). In addition, there was a reduction in concentrations of several amino acids in uterine fluid, most notably the branched amino acids isoleucine, leucine and valine in the blastocyst (asparagine and, at $P<0.10$, hypotaurine, lysine and taurine). 
Consistent with the idea that changes in amino acid availability alters embryonic function through reduced activation of mTORC1 was the finding that blastocysts of mothers fed a low-protein diet had reduced mTORC1 activity, as assessed by phosphorylation of the downstream target S6 ribosomal protein (Eckert et al. 2012). What remains to be seen is whether altered activation of mTORC1 signaling can result in developmental changes that result in the postnatal phenotypes exhibited by offspring of mothers fed low-protein diets during early pregnancy.

Colony-stimulating factor 2 , also called granulocytemacrophage colony-stimulating factor, is another embryokine that has been implicated in developmental programming. This polypeptide is produced by both the oviduct and endometrium (Giacomini et al. 1995; de Moraes et al. 1999; O'Leary et al. 2004; Nahar et al. 2013) particularly by epithelial cells (Giacomini et al. 1995; de Moraes et al. 1999). Moreover, secretion of CSF2 depends on environmental factors of the mother. In particular, seminal plasma triggers expression of CSF2 in the endometrium of the mouse and pig (Tremellen et al. 1998; O'Leary et al. 2004; Bromfield et al. 2014) as does mating in the ewe (Scott et al. 2007). There is also a report in the cow that metabolic status can affect CSF2 expression in the oviduct, with obesity causing reduced expression (Nahar et al. 2013).

Importantly, CSF2 can reverse the deleterious effects of embryo culture in the mouse. Sjöblom et al. (2005) compared postnatal characteristics of mice born following natural mating with those derived from embryos cultured from the twocell to blastocyst stage in medium with or without CSF2. Embryos were transferred into recipients and the postnatal characteristics of the offspring were determined. As shown in Table 3, addition of CSF2 to culture medium either partially or completely prevented the effect of culture on postnatal growth in females and males, relative brain mass in males and placental weight of female progeny when they themselves became pregnant. Addition of CSF2 to medium did not, however, prevent the effect of culture on fatness of males in the postnatal period.

\section{Regulation of the preimplantation embryo by CSF2}

The experiment described above provides strong evidence that CSF2 can modify postnatal phenotype by altering development of the preimplantation embryo. Indeed, CSF2 exerts several actions on the preimplantation embryo that could result in a long-term change in developmental dynamics. In the bovine, these include altered expression of genes involved in pluripotency, differentiation and cell survival (Loureiro et al. 2011), increased ability of isolated inner cell mass (ICM) to remain in a pluripotent state (Dobbs et al. 2013b) and resistance to pro-apoptotic signals (Loureiro et al. 2011). In the mouse, blastocysts cultured with CSF2 in the medium experienced reduced expression of specific genes involved in stress responses and apoptosis (Chin et al. 2009) and fewer apoptotic cells after freeze/thawing (Desai et al. 2007). In the pig, CSF2 affected gene expression in the blastocyst (Kwak et al. 2012a) and increased the ratio of trophectoderm to inner cell mass (Kwak et al. 2012b). Embryos cultured with CSF2 have increased competence to develop to term after transfer to recipient females in the mouse (Sjöblom et al. 2005), cow (Loureiro et al. 2009; Denicol et al. 2014b: embryos produced with X-sorted sperm) and human (Ziebe et al. 2013).

Colony-stimulating factor 2 has also been reported to increase the competence of cultured embryos to develop to the blastocyst stage in the bovine (de Moraes and Hansen 1997; Loureiro et al. 2009; Dobbs et al. 2013b), human (Sjöblom et al. 1999), pig (Cui et al. 2004; Lee et al. 2013) and mouse (Sjöblom et al. 2005). This action of CSF2 has not always been observed, however, as reported for the sheep (Rooke et al. 2005), mouse (Desai et al. 2007; Elaimi et al. 2012;

Table 3 Addition of CSF2 to culture medium reduces some of the effects of embryo culture on postnatal characteristics of the resultant offspring ${ }^{\mathrm{a}}$

\begin{tabular}{|c|c|c|c|c|c|c|}
\hline & \multicolumn{3}{|l|}{ Female } & \multicolumn{3}{|l|}{ Male } \\
\hline & In vivo & In vitro & In vitro + CSF2 & In vivo & In vitro & In vitro + CSF2 \\
\hline Body weight, 5 weeks $(\mathrm{g})^{\mathrm{b}}$ & $21.5 \pm 0.3$ & $22.4 \pm 0.3$ & $21.5 \pm 0.2^{*}$ & - & - & - \\
\hline Body weight, 9 weeks $(\mathrm{g})^{\mathrm{b}}$ & - & - & - & $37.6 \pm 0.5$ & $39.0 \pm 0.5$ & $37.6 \pm 0.4^{*}$ \\
\hline Body weight, 12 weeks (g) & $29.8 \pm 0.9$ & $30.6 \pm 0.7$ & $30.2 \pm 0.8$ & $38.3 \pm 0.8$ & $42.7 \pm 0.8$ & $41.2 \pm 0.8$ \\
\hline Mass of abdominal fat, percent of lean body mass & $4.0 \pm 0.3$ & $4.6 \pm 0.3$ & $4.2 \pm 0.2$ & $4.0 \pm 0.3$ & $5.0 \pm 0.2$ & $4.9 \pm 0.2$ \\
\hline Brain mass, percent of lean body mass & $1.83 \pm 0.05$ & $1.75 \pm 0.05$ & $1.77 \pm 0.04$ & $1.37 \pm 0.03$ & $1.25 \pm 0.03$ & $1.31 \pm 0.03^{*}$ \\
\hline $\begin{array}{l}\text { Placental weight of progeny when they become pregnant } \\
\text { (mg) }\end{array}$ & $93 \pm 2$ & $111 \pm 3$ & $97 \pm 2 *$ & - & - & - \\
\hline
\end{tabular}

* Significantly different from in vitro $(P<0.05)$

${ }^{\text {a }}$ From Sjöblom et al. (2005)

${ }^{\mathrm{b}}$ Maximum differences in weight between groups occurred at 5 weeks for females and 9 weeks for males 
Kim et al. 2014) and bovine (Dobbs et al. 2013b). In the cow, CSF2 increased the percentage of embryos becoming blastocysts when development in controls was low but reduced percent blastocysts when development in controls was high (Dobbs et al. 2013b).

\section{Sexual dimorphism in responses of the preimplantation bovine embryo to CSF2}

Given that many cases of developmental programming are characterized by sexual dimorphism, including programming effects of CSF2 on the mouse embryo (Sjöblom et al. 2005), it is to be expected that some embryokines would regulate preimplantation development of female embryos differently than development of male embryos. Recent experiments in cattle suggest that this is true for CSF2 (Siqueira and Hansen 2015). Furthermore, the consequence is that embryonic function later in development is altered by CSF 2 in a sex-dependent manner (Dobbs et al. 2014).

As mentioned earlier, addition of CSF2 to culture medium of bovine embryos at day 5 after insemination, when the embryo is at the morula stage of development, can increase the percent of embryos that become blastocysts at day 7 after insemination (De Moraes and Hansen 1997; Loureiro et al. 2009). The effect of CSF2 is most pronounced when development of untreated control embryos is low (Dobbs et al. 2013 b). Recently, it has been shown that the prodevelopmental effect of CSF2 also depends on embryo sex. Using X- and Y-sorted spermatozoa to produce embryos that were about $90 \%$ female and male, respectively, Siqueira and Hansen (2015) observed that CSF2 increased the percent of fertilized oocytes becoming blastocysts for females (14.7 \pm 2.1 vs $21.5 \pm 2.1 \%$ ) but not for males ( $16.2 \pm 2.0$ vs $16.3 \pm 2.0 \%$ ).

Exposure of the bovine embryo to CSF2 from days 5 to 7 after insemination also results in a sex-dependent change in development later in pregnancy after embryos are transferred to recipient females (Dobbs et al. 2014). The stage examined was day 15 of gestation when the bovine embryo is undergoing rapid elongation of the trophoblast and secretion of the antiluteolytic molecule interferon- $\tau$ (IFNT) to prevent prostaglandin-induced destruction of the corpus luteum (Spencer et al. 2007). Treatment of in vitro produced embryos with CSF2 from days 5 to 7 of development affected conceptus length and concentrations of IFNT in the uterine lumen at day 15 of pregnancy differently for females than for males. Treatment with CSF2 decreased embryo length and intrauterine accumulation of IFNT in females but increased length and IFNT in males (Fig. 2). Analysis of the transcriptome of extraembryonic membranes also indicated that sex affected the response to CSF2. Treatment caused differential regulation of 94 genes in males and 56 genes in females. Only 7 differentially-regulated genes were regulated in both sexes a



Fig. 2 Interactions between CSF2 treatment from days 5 to 7 of development and sex on embryo length and concentration of IFNT in uterine flushing at day 15 of pregnancy. The figure is reproduced from Biology of Reproduction (Dobbs et al. 2014)

and, in these cases, regulation by CSF2 was always in the opposite direction. Colony-stimulating factor 2 also altered the methylome as assessed using a methylation array containing probes for 418,805 CpG located across the genome. Treatment with CSF2 caused hypermethylation for 6227 probes in females and 9842 probes in males. Hypomethylation was detected for 3292 probes in females and 9322 probes in males. Only 1186 probes were regulated by CSF2 in both sexes and regulation was in the opposite direction for 772 of these probes.

\section{Concluding remarks - a model for sexual dimorphism in developmental programming}

Developmental plasticity in response to the maternal environment is an evolutionary strategy that allows individuals to adapt to the environment during their lifetime, thereby preserving the genotype in the face of transient environmental changes (Gluckman et al. 2007; Warner 2014). Sexual dimorphism in developmental programming may have evolved because the benefit of altered adult phenotype can vary between sexes (Warner 2014) or because the relative importance of 
females and males for evolutionary success depends on the environment (Trivers and Willard 1973). Based on the research reviewed in this paper, it is proposed that sexual dimorphism in developmental programming of mammals during preimplantation development can be dictated by disparate actions of maternally-derived regulatory molecules (i.e., embryokines) on male and female embryos. As a result, alteration in secretion of embryokines in response to environmental change can result in sex-specific deviation in the developmental program.

This hypothesis is shown schematically in Fig. 3 for the example of how changes in the maternal environment might differentially affect growth and function of the bovine embryo as a result of altered secretion of CSF2 from the reproductive tract. In this model, an environmental cue acting on the mother (for example, nutrition) leads to a signal that transmits information about the maternal environment to the embryo. In the illustrated example, the signal is a change in secretion of CSF2 from the maternal reproductive tract. The resultant alteration in the trajectory of development is different for female embryos than male embryos so that subsequent characteristics of the embryo and neonate are modified differently for each sex.

There are many unanswered questions about mechanisms for establishment of sexual dimorphism in programming of postnatal phenotype. While CSF2 can prevent alterations of postnatal phenotype in the mouse caused by embryo culture (Sjöblom et al. 2005), it has not yet been demonstrated that changes in secretion of CSF2 mediate alterations in the developmental program caused by modifications in the maternal environment. There are indeed likely to be an array of embryokines that can program development. Their identification will be critical to understanding mechanisms for developmental programming.

It will also be important to understand how a specific maternal signal can affect the developmental program of a female embryo differently from that of a male embryo. The particular transcriptional and posttranscriptional responses of an embryo to maternal cues are defined by characteristics of the embryo's transcriptome and epigenome. Female and male
Fig. 3 Model illustrating a mechanism for achievement of sex-specific developmental programming in response to a modification in the maternal environment. In this model, a change in the maternal environment alters secretion of uterine embryokines such as CSF2. The resultant deviation in the trajectory of development is different for female embryos than male embryos so that subsequent characteristics of the embryo and neonate are modified differently for each sex. In the particular example of CSF2, exposure to CSF2 from days 5 to 7 after $\mathrm{f}$ ertilization causes different and often opposite actions on development reflected in characteristics of the embryo at day 15 of development




preimplantation embryos differ in both gene expression (Kobayashi et al. 2006; Bermejo-Alvarez et al. 2010; Denicol et al. 2014; Lowe et al. 2015) and the epigenetic landscape (Bermejo-Alvarez et al. 2008; Gebert et al. 2009; Dobbs et al. 2013a). Identification of the specific genes controlling sex differences in response to maternal cues will open up a new understanding of the control of embryonic development in the preimplantation period.

Acknowledgments Recent research from the authors' laboratory discussed in this review was supported by Agriculture and Food Research Initiative Competitive Grant no. 2011-67015-30688 from the USDA National Institute of Food and Agriculture and Grant R03 HD080855 from the National Institutes of Health. LGB Siqueira was financially supported by Embrapa, Brasilia, DF, Brazil.

Conflict of interest The authors declare no conflict of interest.

\section{References}

Armitage JA, Taylor PD, Poston L (2005) Experimental models of developmental programming: consequences of exposure to an energy rich diet during development. J Physiol 565:3-8

Banrezes B, Sainte-Beuve T, Canon E, Schultz RM, Cancela J, Ozil JP (2011) Adult body weight is programmed by a redox-regulated and energy-dependent process during the pronuclear stage in mouse. PLoS ONE 6:e29388

Berg C, Gyllenhammar I, Kvarnryd M (2009) Xenopus tropicalis as a test system for developmental and reproductive toxicity. J Toxicol Environ Health A 72:3-4

Bermejo-Alvarez P, Rizos D, Rath D, Lonergan P, Gutierrez-Adan A (2008) Epigenetic differences between male and female bovine blastocysts produced in vitro. Physiol Genomics 32:264-272

Bermejo-Alvarez P, Rizos D, Rath D, Lonergan P, Gutierrez-Adan A (2010) Sex determines the expression level of one third of the actively expressed genes in bovine blastocysts. Proc Natl Acad Sci U S A 107:3394-3399

Bromfield JJ, Schjenken JE, Chin PY, Care AS, Jasper MJ, Robertson SA (2014) Maternal tract factors contribute to paternal seminal fluid impact on metabolic phenotype in offspring. Proc Natl Acad Sci U S A 111:2200-2205

Calle A, Miranda A, Fernandez-Gonzalez R, Pericuesta E, Laguna R, Gutierrez-Adan A (2012) Male mice produced by in vitro culture have reduced fertility and transmit organomegaly and glucose intolerance to their male offspring. Biol Reprod 87:34

Celeghin A, Benato F, Pikulkaew S, Rabbane MG, Colombo L, Dalla Valle L (2011) The knockdown of the maternal estrogen receptor $2 a$ (esr 2a) mRNA affects embryo transcript contents and larval development in zebrafish. Gen Comp Endocrinol 172:120-129

Chen Z, Robbins KM, Wells KD, Rivera RM (2013) Large offspring syndrome: a bovine model for the human loss-of-imprinting overgrowth syndrome Beckwith-Wiedemann. Epigenetics 8:591-601

Chin PY, Macpherson AM, Thompson JG, Lane M, Robertson SA (2009) Stress response genes are suppressed in mouse preimplantation embryos by granulocyte-macrophage colony-stimulating factor (GMCSF). Hum Reprod 24:2997-3009

Cui XS, Lee JY, Choi SH, Kwon MS, Kim T, Kim NH (2004) Mouse granulocyte-macrophage colony-stimulating factor enhances viability of porcine embryos in defined culture conditions. Anim Reprod Sci 84:169-177 de Moraes AA, Hansen PJ (1997) Granulocyte-macrophage colony-stimulating factor promotes development of in vitro produced bovine embryos. Biol Reprod 57:1060-1065

de Moraes AA, Paula-Lopes FF, Chegini N, Hansen PJ (1999) Localization of granulocyte-macrophage colony-stimulating factor in the bovine reproductive tract. J Reprod Immunol 42:135-145

Denicol AC, Block J, Kelley DE, Pohler KG, Dobbs KB, Mortensen CJ, Ortega MS, Hansen PJ (2014) The WNT signaling antagonist Dickkopf-1 directs lineage commitment and promotes survival of the preimplantation embryo. FASEB J 28:3975-3986

Denicol AC, Leão BCS, Dobbs KB, Mingoti GZ, Hansen PJ (2015) Influence of sex on basal and dickopf-1 regulated gene expression in the bovine morula. PLoS ONE 10, e0133587

Desai N, Kattal N, AbdelHafez FF, Szeptycki-Lawson J, Goldfarb J (2007) Granulocyte-macrophage colony stimulating factor (GMCSF) and co-culture can affect post-thaw development and apoptosis in cryopreserved embryos. J Assist Reprod Genet 24:215-222

Desai M, Jellyman JK, Ross MG (2015) Epigenomics, gestational programming and risk of metabolic syndrome. Int J Obes (Lond) 39: $633-641$

Dobbs KB, Rodriguez M, Sudano MJ, Ortega MS, Hansen PJ (2013a) Dynamics of DNA methylation during early development of the preimplantation bovine embryo. PLoS ONE 8, e66230

Dobbs KB, Khan FA, Sakatani M, Moss JI, Ozawa M, Ealy AD, Hansen PJ (2013b) Regulation of pluripotency of inner cell mass and growth and differentiation of trophectoderm of the bovine embryo by colony stimulating factor 2. Biol Reprod 89:141

Dobbs KB, Gagné D, Fournier E, Dufort I, Robert C, Block J, Sirard MA, Bonilla L, Ealy AD, Loureiro B, Hansen PJ (2014) Sexual dimorphism in developmental programming of the bovine preimplantation embryo caused by colony-stimulating factor 2. Biol Reprod 91:80

Ecker DJ, Stein P, Xu Z, Williams CJ, Kopf GS, Bilker WB, Abel T, Schultz RM (2004) Long-term effects of culture of preimplantation mouse embryos on behavior. Proc Natl Acad Sci U S A 101:15951600

Eckert JJ, Porter R, Watkins AJ, Burt E, Brooks S, Leese HJ, Humpherson PG, Cameron IT, Fleming TP (2012) Metabolic induction and early responses of mouse blastocyst developmental programming following maternal low protein diet affecting life-long health. PLoS ONE 7, e52791

El Hajj N, Schneider E, Lehnen H, Haaf T (2014) Epigenetics and lifelong consequences of an adverse nutritional and diabetic intrauterine environment. Reproduction 148:R111-R2120

Elaimi A, Gardner K, Kistnareddy K, Harper J (2012) The effect of GMCSF on development and aneuploidy in murine blastocysts. Hum Reprod 27:1590-1595

Farin CE, Farmer WT, Farin PW (2010) Pregnancy recognition and abnormal offspring syndrome in cattle. Reprod Fertil Dev 22:75-87

Fernández-Gonzalez R, Moreira P, Bilbao A, Jiménez A, Pérez-Crespo M, Ramírez MA, Rodríguez De Fonseca F, Pintado B, GutiérrezAdán A (2004) Long-term effect of in vitro culture of mouse embryos with serum on mRNA expression of imprinting genes, development, and behavior. Proc Natl Acad Sci U S A 101:5880-5885

Fisher RE, Steele M, Karrow NA (2012) Fetal programming of the neuroendocrine-immune system and metabolic disease. J Pregnancy 2012:792934

Fisher RE, Or'Rashid M, Quinton M, AlZahal O, Boermans HJ, McBride BW, Karrow NA (2014) Maternal supplementation with fishmeal protects against late gestation endotoxin-induced fetal programming of the ovine hypothalamic-pituitary-adrenal axis. J Dev Orig Health Dis 5:206-213

Fleming TP, Velazquez MA, Eckert JJ (2015) Embryos, DOHaD and David Barker. J Dev Orig Health Dis 8:1-7

Gad A, Hoelker M, Besenfelder U, Havlicek V, Cinar U, Rings F, Held E, Dufort I, Sirard MA, Schellander K, Tesfaye D (2012) Molecular mechanisms and pathways involved in bovine embryonic genome 
activation and their regulation by alternative in vivo and in vitro culture conditions. Biol Reprod 87:100

Ganu RS, Harris RA, Collins K, Aagaard KM (2012) Early origins of adult disease: approaches for investigating the programmable epigenome in humans, nonhuman primates, and rodents. ILAR J 53:306321

Gebert C, Wrenzycki C, Herrmann D, Gröger D, Thiel J, Reinhardt R, Lehrach H, Hajkova P, Lucas-Hahn A, Carnwath JW, Niemann H (2009) DNA methylation in the IGF2 intragenic DMR is reestablished in a sex-specific manner in bovine blastocysts after somatic cloning. Genomics 94:63-69

Giacomini G, Tabibzadeh SS, Satyaswaroop PG, Bonsi L, Vitale L, Bagnara GP, Strippoli P, Jasonni VM (1995) Epithelial cells are the major source of biologically active granulocyte macrophage colony-stimulating factor in human endometrium. Hum Reprod 10:3259-3263

Gluckman PD, Hanson MA, Beedle AS (2007) Early life events and their consequences for later disease: a life history and evolutionary perspective. Am J Hum Biol 19:1-19

Hales CN, Barker DJ (2001) The thrifty phenotype hypothesis. Br Med Bull 60:5-20

Hansen PJ, Dobbs KB, Denicol AC (2014a) Programming of the preimplantation embryo by the embryokine colony stimulating factor 2 . Anim Reprod Sci 149:59-66

Hansen PJ, Denicol AC, Dobbs KB (2014b) Maternal embryokines that regulate development of the bovine preimplantation embryo. Turk J Vet Anim Sci 38:589-598

Hernandez CE, Matthews LR, Oliver MH, Bloomfield FH, Harding JE (2010) Effects of sex, litter size and periconceptional ewe nutrition on offspring behavioural and physiological response to isolation. Physiol Behav 101:588-594

Kang HJ, Hwang SJ, Yoon JA, Jun JH, Lim HJ, Yoon TK, Song H (2011) Activation of peroxisome proliferators-activated receptor $\delta$ (PPAR $\delta$ ) promotes blastocyst hatching in mice. Mol Hum Reprod 17:653660

Khalyfa A, Carreras A, Almendros I, Hakim F, Gozal D (2015) Sex dimorphism in late gestational sleep fragmentation and metabolic dysfunction in offspring mice. Sleep 38:545-557

Kim JH, Lee HJ, Yu EJ, Jee BC, Suh CS, Kim SH (2014) Dosedependent embryotrophic effect of recombinant granulocytemacrophage colony-stimulating factor and brain-derived neurotrophic factor in culture medium for mouse preimplantation embryo. Obstet Gynecol Sci 57:373-378

Kobayashi S, Isotani A, Mise N, Yamamoto M, Fujihara Y, Kaseda K, Nakanishi T, Ikawa M, Hamada H, Abe K, Okabe M (2006) Comparison of gene expression in male and female mouse blastocysts revealed imprinting of the X-linked gene, Rhox $5 / \mathrm{Pem}$, at preimplantation stages. Curr Biol 16:166-172

Kwak SS, Cheong SA, Jeon Y, Hyun SH (2012a) Porcine granulocytemacrophage colony-stimulating factor improves the in vitro development of cloned porcine embryos. J Vet Med Sci 74:1095-1102

Kwak SS, Jeung SH, Biswas D, Jeon YB, Hyun SH (2012b) Effects of porcine granulocyte-macrophage colony-stimulating factor on porcine in vitro-fertilized embryos. Theriogenology 77:1186-1197

Kwong WY, Wild AE, Roberts P, Willis AC, Fleming TP (2000) Maternal undernutrition during the preimplantation period of rat development causes blastocyst abnormalities and programming of postnatal hypertension. Development 127:4195-4202

Kwong WY, Miller DJ, Ursell E, Wild AE, Wilkins AP, Osmond C, Anthony FW, Fleming TP (2006) Imprinted gene expression in the rat embryo-fetal axis is altered in response to periconceptional maternal low protein diet. Reproduction 132:265-277

Lee K, Redel BK, Spate L, Teson J, Brown AN, Park KW, Walters E, Samuel M, Murphy CN, Prather RS (2013) Piglets produced from cloned blastocysts cultured in vitro with GM-CSF. Mol Reprod Dev $80: 145-154$
Loureiro B, Bonilla L, Block J, Fear JM, Bonilla AQ, Hansen PJ (2009) Colony-stimulating factor 2 (CSF-2) improves development and posttransfer survival of bovine embryos produced in vitro. Endocrinology 150:5046-5054

Loureiro B, Oliveira LJ, Favoreto MG, Hansen PJ (2011) Colonystimulating factor 2 inhibits induction of apoptosis in the bovine preimplantation embryo. Am J Reprod Immunol 65:578-588

Lowe R, Gemma C, Rakyan VK, Holland ML (2015) Sexually dimorphic gene expression emerges with embryonic genome activation and is dynamic throughout development. BMC Genomics 16:295

Lucas E (2013) Epigenetic effects on the embryo as a result of periconceptional environment and assisted reproduction technology. Reprod Biomed Online 27:477-485

Martin PM, Sutherland AE, Van Winkle LJ (2003) Amino acid transport regulates blastocyst implantation. Biol Reprod 69:1101-1108

Meier S, Craig Morton H, Nyhammer G, Grøsvik BE, Makhotin V, Geffen A, Boitsov S, Kvestad KA, Bohne-Kjersem A, Goksøyr A, Folkvord A, Klungsøyr J, Svardal A (2010) Development of Atlantic cod (Gadus morhua) exposed to produced water during early life stages: Effects on embryos, larvae, and juvenile fish. Mar Environ Res 70:383-394

Micke GC, Sullivan TM, Gatford KL, Owens JA, Perry VE (2010) Nutrient intake in the bovine during early and mid-gestation causes sex-specific changes in progeny plasma IGF-I, liveweight, height and carcass traits. Anim Reprod Sci 121:208-217

Nahar A, Maki S, Kadokawa H (2013) Suppressed expression of granulocyte macrophage colony-stimulating factor in oviduct ampullae of obese cows. Anim Reprod Sci 139:1-8

O'Leary S, Jasper MJ, Warnes GM, Armstrong DT, Robertson SA (2004) Seminal plasma regulates endometrial cytokine expression, leukocyte recruitment and embryo development in the pig. Reproduction 128:237-247

Palou M, Konieczna J, Torrens JM, Sánchez J, Priego T, Fernandes ML, Palou A, Picó C (2012) Impaired insulin and leptin sensitivity in the offspring of moderate caloric-restricted dams during gestation is early programmed. J Nutr Biochem 23:1627-1639

Rivera RM, Ross JW (2013) Epigenetics in fertilization and preimplantation embryo development. Prog Biophys Mol Biol 113:423-432

Rooke J, Ewen M, McEvoy T, Entrican G, Ashworth C (2005) Effect of inclusion of serum and granulocyte-macrophage colony stimulating factor on secretion of interferon-tau during the in vitro culture of ovine embryos. Reprod Fertil Dev 17:513-521

Roseboom TJ, van der Meulen JH, Ravelli AC, Osmond C, Barker DJ, Bleker OP (2001) Effects of prenatal exposure to the Dutch famine on adult disease in later life: an overview. Mol Cell Endocrinol 185: 93-98

Sampino S, Zacchini F, Swiergiel AH, Modlinski AJ, Loi P, Ptak GE (2014) Effects of blastomere biopsy on post-natal growth and behavior in mice. Hum Reprod 29:1875-1883

Schwanz LE, Ezaz T, Gruber B, Georges A (2013) Novel evolutionary pathways of sex-determining mechanisms. J Evol Biol 26:2544 2557

Scott JL, Ketheesan N, Summers PM (2007) Granulocyte-macrophage colony stimulating factor and interleukin- 8 in the reproductive tract of ewes following oestrus and mating. Reprod Fertil Dev 19:585593

Serrano A, Decara JM, Fernández-González R, López-Cardona AP, Pavón FJ, Orio L, Alen F, Gutiérrez-Adán A, de Fonseca FR (2014) Hyperplastic obesity and liver steatosis as long-term consequences of suboptimal in vitro culture of mouse embryos. Biol Reprod 91:30

Siqueira LGB, Hansen PJ (2015) Colony-stimulating factor 2 affects development of the bovine preimplantation embryo differently for females than males. J Anim Sci (in press) (Abstr) 
Sjöblom C, Wikland M, Robertson SA (1999) Granulocyte-macrophage colony-stimulating factor promotes human blastocyst development in vitro. Hum Reprod 14:3069-3076

Sjöblom C, Roberts CT, Wikland M, Robertson SA (2005) Granulocytemacrophage colony-stimulating factor alleviates adverse consequences of embryo culture on fetal growth trajectory and placental morphogenesis. Endocrinology 146:2142-2153

Spencer TE, Johnson GA, Bazer FW, Burghardt RC, Palmarini M (2007) Pregnancy recognition and conceptus implantation in domestic ruminants: roles of progesterone, interferons and endogenous retroviruses. Reprod Fertil Dev 19:65-78

Sun C, Velazquez MA, Marfy-Smith S, Sheth B, Cox A, Johnston DA, Smyth N, Fleming TP (2014) Mouse early extra-embryonic lineages activate compensatory endocytosis in response to poor maternal nutrition. Development 141:1140-1150

Sun C, Denisenko O, Sheth B, Cox A, Lucas ES, Smyth NR, Fleming TP (2015) Epigenetic regulation of histone modifications and Gata6 gene expression induced by maternal diet in mouse embryoid bodies in a model of developmental programming. BMC Dev Biol 15:3

Taylor AH, Amoako AA, Bambang K, Karasu T, Gebeh A, Lam PM, Marzcylo TH, Konje JC (2010) Endocannabinoids and pregnancy. Clin Chim Acta 411:921-930

Tremellen KP, Seamark RF, Robertson SA (1998) Seminal transforming growth factor betal stimulates granulocyte-macrophage colonystimulating factor production and inflammatory cell recruitment in the murine uterus. Biol Reprod 58:1217-1225

Trivers RL, Willard DE (1973) Natural selection of parental ability to vary the sex ratio of offspring. Science 179:90-92

Urrego R, Rodriguez-Osorio N, Niemann H (2014) Epigenetic disorders and altered gene expression after use of Assisted Reproductive Technologies in domestic cattle. Epigenetics 9:803-815

Walker CL, Ho SM (2012) Developmental reprogramming of cancer susceptibility. Nat Rev Cancer 12:479-486

Warner DA (2014) Fitness consequences of maternal and embryonic responses to environmental variation: using reptiles models for studies of developmental plasticity. Integr Comp Biol 54:757-773
Watkins AJ, Platt D, Papenbrock T, Wilkins A, Eckert JJ, Kwong WY, Osmond C, Hanson M, Fleming TP (2007) Mouse embryo culture induces changes in postnatal phenotype including raised systolic blood pressure. Proc Natl Acad Sci U S A 104:5449-5454

Watkins AJ, Ursell E, Panton R, Papenbrock T, Hollis L, Cunningham C, Wilkins A, Perry VH, Sheth B, Kwong WY, Eckert JJ, Wild AE, Hanson MA, Osmond C, Fleming TP (2008) Adaptive responses by mouse early embryos to maternal diet protect fetal growth but predispose to adult onset disease. Biol Reprod 78:299-306

Watkins AJ, Lucas ES, Torrens C, Cleal JK, Green L, Osmond C, Eckert JJ, Gray WP, Hanson MA, Fleming TP (2010) Maternal low-protein diet during mouse pre-implantation development induces vascular dysfunction and altered renin-angiotensin-system homeostasis in the offspring. Br J Nutr 103:1762-1770

Watkins AJ, Lucas ES, Wilkins A, Cagampang FR, Fleming TP (2011) Maternal periconceptional and gestational low protein diet affects mouse offspring growth, cardiovascular and adipose phenotype at 1 year of age. PLoS ONE 6:e28745

Watkins AJ, Lucas ES, Marfy-Smith S, Bates N, Kimber SJ, Fleming TP (2015) Maternal nutrition modifies trophoblast giant cell phenotype and fetal growth in mice. Reproduction 149:563-575

Williams CL, Teeling JL, Perry VH, Fleming TP (2011) Mouse maternal systemic inflammation at the zygote stage causes blunted cytokine responsiveness in lipopolysaccharide-challenged adult offspring. BMC Biol 9:49

Wood-Bradley RJ, Barrand S, Giot A, Armitage JA (2015) Understanding the role of maternal diet on kidney development; an opportunity to improve cardiovascular and renal health for future generations. Nutrients 7:1881-1905

Ziebe S, Loft A, Povlsen BB, Erb K, Agerholm I, Aasted M, Gabrielsen A, Hnida C, Zobel DP, Munding B, Bendz SH, Robertson SA (2013) A randomized clinical trial to evaluate the effect of granulocyte-macrophage colony-stimulating factor (GM-CSF) in embryo culture medium for in vitro fertilization. Fertil Steril 99: 1600-1609 